\title{
ERRATUM
}

Genes \& Development 35: 692-697 (2021)

\section{Erratum: Meikin synergizes with shugoshin to protect cohesin Rec8 during meiosis I}

Wei Ma, Jingwen Zhou, Jian Chen, Antony M. Carr, and Yoshinori Watanabe

For the above-mentioned paper, the associated Creative Commons license has been updated to CC-BY-NC, correcting an inadvertent error made during the production process. The updated license is reflected in the final version of the article online.

doi: $10.1101 / \operatorname{gad} .348698 .121$ 


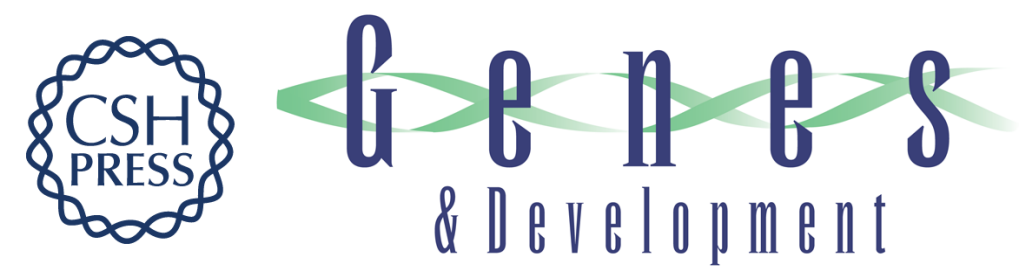

\section{Erratum: Meikin synergizes with shugoshin to protect cohesin Rec8 during meiosis I}

Wei Ma, Jingwen Zhou, Jian Chen, et al.

Genes Dev. 2021, 35:

Access the most recent version at doi:10.1101/gad.348698.121

\section{Related Content Meikin synergizes with shugoshin to protect cohesin Rec8 during meiosis I Wei Ma, Jingwen Zhou, Jian Chen, et al. \\ Genes Dev. May , 2021 35: 692-697}

\section{License}

Email Alerting

Receive free email alerts when new articles cite this article - sign up in the box at the top

Service right corner of the article or click here.

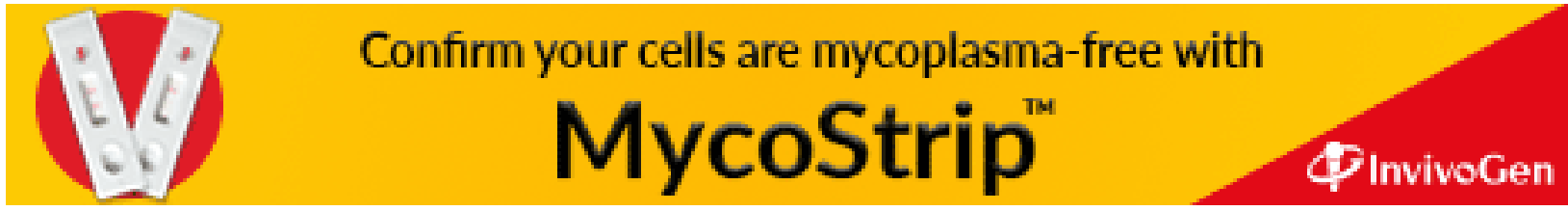

